\title{
Energy transfer in co-doped Nal:(TI,Eu) crystals
}

\author{
S.Gridin $^{1,2}$, S.Vasyukov ${ }^{1}$, N.Shiran ${ }^{1}$, A.Gektin ${ }^{1}$ \\ ${ }^{1}$ Institute for Scintillation Materials, 60 Lenin Avenue, 61001 Kharkov, \\ Ukraine \\ 2Institut Lumiere Matiere, Universite Claude Bernard Lyon 1, \\ 69622 Villeurbanne Cedex, France
}

Received 7 September, 2014

The energy transfer mechanism in Eu doped and $\mathrm{Tl}$, Eu co-doped NaI crystals is discussed. The self-trapped exciton emission band overlaps stronger with $\mathrm{Eu}^{2+}$ excitation bands rather that with $\mathrm{Tl}^{+}$. This suggests that transfer STE $\rightarrow$ Activator can be more efficient in $\mathrm{Eu}^{2+}$ co-doped Nal:Tl crystals. Theoretical estimation of energy transfer efficiency was done based on the Forster model. It is shown that Europium concentration of 1 mass $\%$ or above is required for efficient dipole-dipole energy transfer. However, this concentration is not reachable in $\mathrm{Nal}:(\mathrm{TI}, \mathrm{Eu})$ due to the solubility limit of $\mathrm{Eu}^{2+}$ in $\mathrm{Nal}$ crystal.

Обсуждается механизм передачи энергии в активированных Еи и соактивированных $\mathrm{Tl}$ и Eu кристаллах Nal. Полоса излучения автолокализованного экситона (АЛЭ) перекрывается сильнее с уровнями возбуждения $\mathrm{Eu}^{2+}$, чем в случае $\mathrm{Tl}^{+}$. Это говорит о том, что передача АЛЭ $\rightarrow$ Активатор может быть более әффективной в $\mathrm{Eu}^{2+}$ соактивированных кристаллах $\mathrm{Nal}: \mathrm{Tl}$. Теоретическая оценка әффективности переноса энергии осуществлялась на основе модели Фестера. Показано, что для әффективного диполь-дипольного переноса энергии необходима концентрация европия 1 масс $\%$ или выше. Однако, эта концентрация не достижима в $\mathrm{Nal}(\mathrm{Tl}, \mathrm{Eu})$ из-за пределов растворимости $\mathrm{Eu}^{2+}$ в кристалле Nal.

\footnotetext{
Перенос енергіï в соактивованих кристалах Nal:(TI,Eu). C.Грідін, С.Васюков, Н.Ширан, А.Гектин

Обговорюється механізм передачі енергії в активованих Eu i соактивованих TL та Eu кристалах Nal. Смуга випромінювання автолокалізованого екситону (АЛЕ) перекривається сильніше з рівнями збудження $\mathrm{Eu}^{2+}$, ніж у випадку $\mathrm{Tl}^{+}$. Це говорить про те, що передача АЛЕ $\rightarrow$ Активатор може бути більш ефективною в $\mathrm{Eu}^{2+}$ соактивованих кристалах Nal:Tl. Теоретична оцінка ефективності переносу енергії здійснювалася на основі моделі Фестера. Показано, що для ефективної диполь-дипольної передачі енергії необхідна концентрація європію 1 мас\% або вище. Однак, така концентрація не досяжна в $\mathrm{Nal}:(\mathrm{Tl}, \mathrm{Eu})$ у зв'язку з межами розчинності $\mathrm{Eu}^{2+}$ в кристалі $\mathrm{Nal}$.
}

\section{Introduction}

As it was shown in our previous works, co-doping of Nal:TI and Csl:Tl classical scintillators with $\mathrm{Eu}^{2+}$ can improve some scintillation properties. In case of Csl:(TI,Eu) europium halides added into the melt during the crystals growth as scavengers [1]. This ef- fect results in suppression of the scintillation afterglow. In case of Nal scintillator presence of $\mathrm{Eu}^{2+}$ ions in the crystal lattice was found to significantly change its luminescent properties [2]. Besides, the light yield improvement was found in Eu co-doped Nal:TI crystals [3]. 
Goal of the present work is to investigate possible mechanisms of the light yield improvement in Nal:(TI,Eu) crystals. Fluorescent spectroscopy methods were used to study the interaction between the intrinsic and activator-induced emission centers.

\section{Experimental}

The series of Nal:Eu, Nal:TI and Nal:(TI, Eu) single crystal boules $25-35 \mathrm{~mm}$ in diameter and $100-200 \mathrm{~mm}$ in height were grown by the Czochralski method of automated pulling from the melt in controlled reactive atmosphere. Due to the crystals' high hygroscopicity all the processing was performed in the dry boxes only. The Europium concentration in samples was varied from 10-5 to $0.5 \mathrm{mass} \% \mathrm{Eu}^{2+}$ and determined by chemical and absorption methods.

The absorption spectra were measured by means of SPECORD 40 spectrophotom-eter. Spectral and kinetic characteristics of photoemission were studied using FLS920 combined steady state and fluorescence life-time spectrometer manufactured by Edinb. Instr. Ltd. A Xe900 steady state xenon lamp was used in the continuous mode for UV spectroscopy. The spectroscopic investigation of crystals emission was performed at the SUPERLUMI setup of HASYLAB at DESY (Hamburg, Germany) under synchrotron radiation excitation.

\section{Results and discussion}

Europium concentration in Nal:(TI,Eu) was varied to obtain a set of samples with different $\mathrm{Eu}^{2+}$ content. It was found that the increase of europium leads to a significant change in the emission spectrum (Fig. 1). At higher europium concentration then thallium or neighbour concentration the emission spectrum of $\mathrm{Nal}$ (Tl,Eu) crystals contains mostly the $\mathrm{Eu}^{2+}$ related emission band peaking around $440 \mathrm{~nm}$ (Fig. 1, b). Thallium characteristic emission which is normally peaking around $410 \mathrm{~nm}$ in Nal:TI (Fig. 1, a) is strongly suppressed by Eu. Measurements of excitation spectra for $\mathrm{Eu}^{2+}$ emission (440 $\mathrm{nm}$ band) in Nal:(TI,Eu) reveal the overlap of $\mathrm{Tl}^{+}$emission band with Eu absorption. This overlapping suggests the energy transfer between the activator centers.

Apart the overlapping between $\mathrm{Tl}^{+}$emission and $\mathrm{Eu}^{2+}$ absorption, the overlap between self-trapped excitons (STE) emission band should be also noted. Low temperature emission of STE is peaking around $300 \mathrm{~nm}$ in Nal crystals (Fig. 2). Even though STE

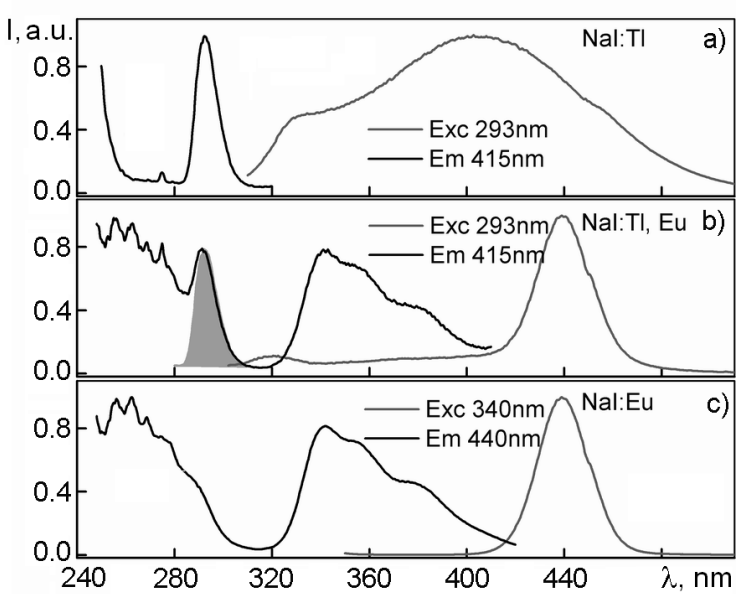

Fig. 1. Excitation and emission spectra of Nal:TI (a), Nal:(TI,Eu) (b) and Nal:Eu (c) crystals measured at $300 \mathrm{~K}$.

luminescence is quenched at room temperature, non-radiative resonance energy transfer from exciton to activator is still possible. According to Fig. 2, the STE emission band overlaps stronger with $\mathrm{Eu}^{2+}$ excitation bands rather that with $\mathrm{Tl}^{+}$. This suggests that transfer STE $\rightarrow$ Activator can be more efficient in $\mathrm{Eu}^{2+}$ co-doped $\mathrm{Nal}: \mathrm{Tl}$ crystals.

In general, energy from donors to acceptors can be transferred by the non-radiative Forster resonant energy transfer mechanism or by re-absorption of the donors' emission by acceptors. The former mechanism is required for improvement of scintillation properties.

Resonance energy transfer occurs due to multipole Coulomb interaction of the impurity ions in case of overlapping donor luminescence and acceptor absorption lines [4]. Probability of the Forster resonance energy transfer (FRET) can be estimated using the following expression:

$$
W=\frac{3 \pi \hbar e^{4} f_{1} f_{2}}{n^{4} m^{2} w^{2} R^{6}} \int g_{1}(E) g_{2}(E) d E,
$$

where $n$ - refractive index; $m$ - mass of the electron; $e$ - electron charge; $R$ - distance between interacting ions; $\int g_{1}(E) g_{2}(E) d E-$ the overlapping integral of the luminescence spectrum of the donor $g_{1}(E)$ and the absorption spectrum of the acceptor $g_{2}(E)$ in case of $\int g_{1}(E) d E=1$ and $\int g_{2}(E) d E=1 ; w-$ the average frequency overlap; $f_{1}$ and $f_{2}-$ the oscillator strengths of the transitions donor and acceptor ions corresponding. 


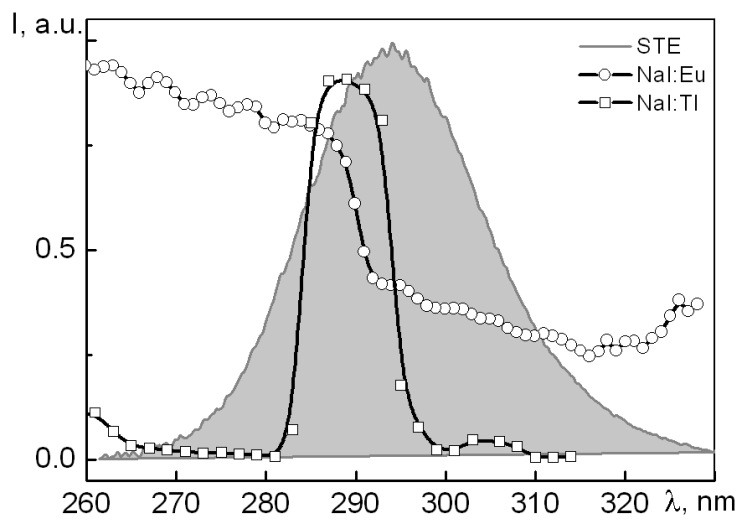

Fig. 2. Emission spectrum of self-trapped excitons in $\mathrm{Nal}$, overlapping with $\mathrm{Eu}^{2+}$ and $\mathrm{Tl}^{+}$ excitation spectra measured at $10 \mathrm{~K}$.

FRET efficiency in Nal:(TI,Eu) can be estimated based on the equation (1) using FRET efficiency in Nal:(Tl,Eu) can be estimated based on the equation (1) using Photochem CAD simulation software. Estimation of dipole-dipole energy transfer efficiency and average distance between ions as function of activators content is shown in Fig. 3. Based on the spectral overlap method used, non-radiative dipole-dipole transfer is possible in case of short donor-acceptor distance D, less than 3-4 nm (Fig. 3, a). Based on Fig. 3, b europium concentration of $10^{-1}$ mass $\%$ or higher is required to make sure the average distance between the acceptors is 4-5 $\mathrm{nm}$. However, aggregation of europium ions in $\mathrm{Nal}$ was observed at $\mathrm{Eu}$ concentrations above $10^{-2}-10^{-1} \operatorname{mass} \%$ and higher [2]. This suggests that dipole-dipole transition $\mathrm{Tl} \rightarrow \mathrm{Eu}$ is limited due to poor solubility of $\mathrm{Eu}^{2+}$ in $\mathrm{Nal}$.

Anyway, energy transfer mechanism $\mathrm{TI} \rightarrow \mathrm{Eu}$ is not expected to cause any improvement of light yield observed in [3]. On the other hand, gain in Nal:(TI,Eu) scintillation efficiency can be explained by the energy transfer from STE to $\mathrm{Eu}^{2+}$ emission centers. As it was suggested in $[5,6]$, quenching of STE excited states can be the major reason of energy losses in alkali halide scintillators at RT. In this respect, the energy transfer of exciton to emission centers can be the source of the light yield increase at RT. Since $\mathrm{Eu}^{2+}$ excitation energy levels coincide with STE emission in Nal (Fig. 2), energy transfer from excitons to Eu emission center is possible. However, efficiency of $\mathrm{STE} \rightarrow \mathrm{Eu}^{2+}$ transfer is limited by the concentration of activator as shown in Fig 3. In order to fully benefit from this transfer,
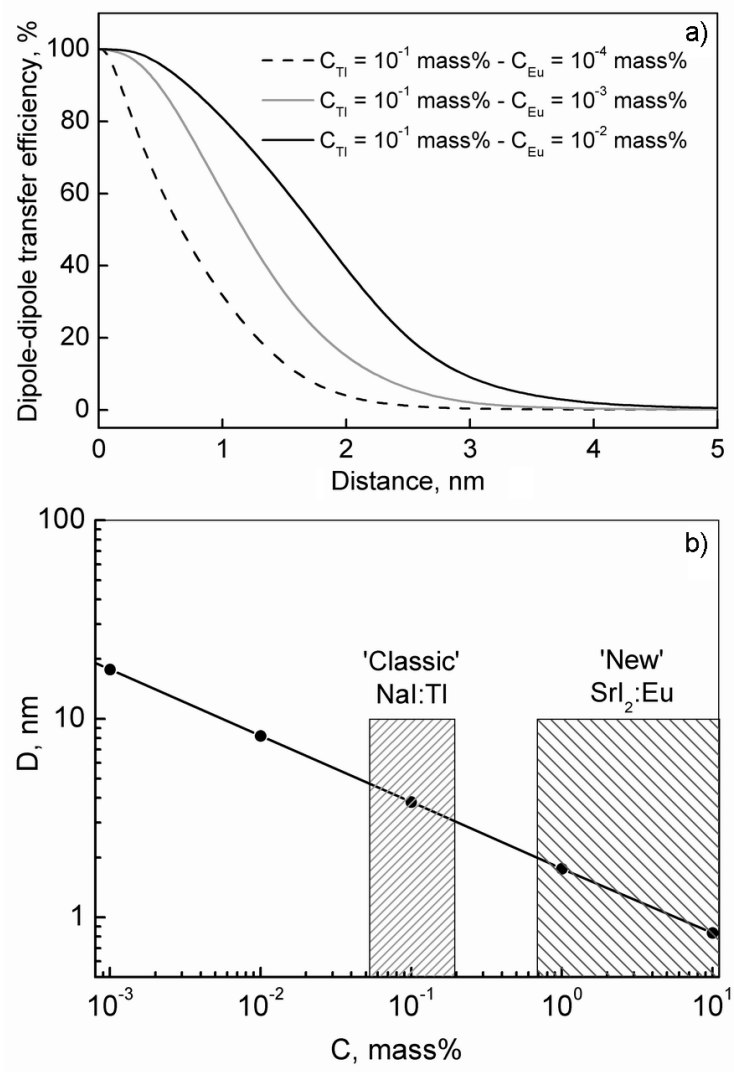

Fig. 3. $a$ - Efficiency of dipole-dipole energy transfer mechanism versus distance between ions; $b$ - average distance between activator ions as a function of activator concentration. Rectangles marked concentration which achieves good scintillation efficiency for 'Classic' and 'New' materials. The value $D$ estimated using the following expression: $D=\frac{1}{\sqrt[3]{N}}$, where $N$ - activator ions per $\mathrm{cm}^{3}$.

Europium concentration about 1 mass $\%$ is required (Fig. 3, b). This can be the case for many Eu-doped alkali-earth halide scintillators such as $\mathrm{Srl}_{2}: \mathrm{Eu}$, BaBrl:Eu etc $[7,8]$.

\section{Conclusions}

Improvement of Nal:TI scintillation yield by europium co-doping is considered. We suggest that emission centers created by $\mathrm{Eu}^{2+}$ in $\mathrm{Nal}$ can benefit from excitonic energy transfer from the crystal matrix. Probability of this transfer is estimated for the case of Forster resonance mechanism. It is shown that europium concentration of 1 mass $\%$ or above is required for efficient dipole-dipole energy transfer. However, this concentration is not reachable in Nal:(TI,Eu) due to the solubility limit of $\mathrm{Eu}^{2+}$ in $\mathrm{Nal}$ crystal. 


\section{References}

1. N. Shiran, A. Gektin, S. Vasyukov, S. Tkachenko, D. Sofronov, Functional Materials, 18, 4 (2011) 438-441.

2. N. Shiran, A. Gektin, Y. Boyarintseva, S. Vasyukov et al., Opt. Mater., 32 , 1345 (2010).

3. N.Shiran, A.Gektin, Y.Boyarintseva, S. Vasyukov et al., IEEE TNS, 57, 3, (2010).

4. Th. Forster, Rad. Res. Supplement 2, 326 (1960).
5. A. Gektin, S. Gridin, S. Vasyukov, A. Vasil'ev et al., Phys. Status Solidi B, 1 (2014) DOI 10.1002/pssb.201451399.

6. S. Gridin, A. N. Vasil'ev, A. Belsky, N. Shiran, A. Gektin, Phys. Status Solidi B, 1 (2014) DOI 10.1002/pssb.201350234.

7. N. Cherepy, G. Hull, A. Drobshoff, S. Payne et al., Appl. Phys. Lett., 92, 083508 (2008).

8. E.D. Bourret-Courchesne, G. Bizarri, S.M. Hanrahan et al., Nuclear Instr. Meth. Phys. Res., A 613 (2010) 95-97. 